\title{
Peertechz
}

\section{Lipid nanoparticulate drug delivery system for the treatment of hepatic fibrosis}

\section{Swarupananda Mukherjee ${ }^{1 *}$, Ayon Dutta ${ }^{2}$ and Dipanjana $\mathrm{Ash}^{3}$}

${ }^{1}$ Assistant Professor, Department of Pharmacy, NSHM Knowledge Campus, Kolkata - Group of Institutions, 124 B.L.Saha Road, Kolkata- 700053,West Bengal, India

${ }^{2}$ Assistant Professor, Department of Pharmaceutical Technology, Bengal School of Technology (A College of Pharmacy), Delhi Road, Sugandha, Hoogly, Pin-712102, West Bengal, India

${ }^{3}$ Assistant Professor, Department of Pharmaceutics, BCDA College of Pharmacy and Technology, 78/1 Jessore Road (S), Hridaypur, Barasat, Kolkata-700127, West Bengal, India
Received: 11 January, 2021

Accepted: 25 January, 2021

Published: 28 January, 2021

*Corresponding author: Swarupananda Mukherjee, Department of Pharmacy, NSHM Knowledge Campus, Kolkata, Group of Institutions, 124 B.L.Saha Road, Kolkata - 700053, West Bengal, India, Tel: +91 905116425; Email: swarup_mukherjee@rediffmail.com, swarupananda.mukherjee@nshm.com

Keywords: Chemokines; Interferon; Hepatic; Transforming; Receptor

https://www. peertechz.com

Check for updates

\section{Abstract}

Background: Irreversible hepatic fibrosis, an excessive production and accumulation of extra cellular matrix by hepatic stellate cells in the liver, becomes a remarkable economic burden in global health care system.Low therapeutic efficacy and undesirable systemic effect of conventional therapies limit their clinical applications to targethepatic stellate cells.

Method: Surface engineered lipid nano-particle becomes a potential candidate to deliver anti-fibrotic nutrients or Small interfering RNA (siRNA) of fibrogenic genes for treating hepatic disorders.

Conclusion: This mini review focuses on different strategies of surface engineered organic lipid nanoparticles for the treatment of hepatic fibrosis by targeting specific and un-specific Hepatic Stellate Cells (HSCs).

\section{Abbreviations}

CXCR4: Chemokines Receptor Type 4; ECM: Extra Cellular Matrix; HA: Hyaluronic Acid; HSCs: Hepatic Stellate Cells; IFN$\alpha-1 b$ : Interferon- $\alpha-1 b ;$ M6P/IGF II: Mannose-6- Phosphate/ insulin-Like Growth Factor II; PDGF- $\beta$ : Platelet-Derived Growth Factor Receptor; RBP: Retinol Binding Protein; siRNA: small interfering RNA; TGF- $\beta 1$ : Transforming Growth Factor- $\beta 1$

\section{Introduction}

In $21^{\text {st }}$ century Hepatic disorders such ashepatitis; hepatic fibrosis;cirrhosis; and hepatocellular carcinoma, the considerable economical burden on global healthcare infrastructure, accounts for $5-10 \%$ of total mortality in the world per year due to restrictedtreatment option. Hepatic fibrosis is the excessive accumulation of Extra Cellular Matrix
(ECM) protein including collagen in the liver attributed tothe trans-differentiation of HSC by fibrogenic cytokines such as Transforming Growth Factor- $\beta 1$ (TGF- $\beta 1$ ), angiotensin II, and leptin and ultimately resulting in the further development of cirrhosis, liver failure and portal hypertension due to deformation of hepatic architecture and evolution of regenerating hepatocytes nodules. Hepatitis C, alcohol abuse and non-alcoholic steatohepatitis have been recognized as a major cause of irreversible hepatic fibrosis. Therefore, HSC becomes a cellular target for the treatment of hepatic fibrosis [1]. Low therapeutic efficacy and undesirable systemic effect of standard conventional therapies limit their clinical applications in this field.Nano-material based drug delivery systems such as Lipid, polymeric, inorganic and protein nanoparticles have been shown an exceptional potential for novel therapeutic approaches to deliver anti-fibrotic nutrients 
or siRNA of fibrogenic genes for treating hepatic disorders [2] Their ease of surface modification, encapsulation efficiency, bio-compatibility, bio-degradability, physico-chemical stability, feasibility in scaling up and target specificity offer great advantages [3]. This mini review focuses on surface engineering of organic lipid nanoparticles for the treatment of hepatic fibrosis via specific and un-specific HSC-targeting.

Methodology, selection criteria, inclusion and exclusion criteria for the preparation of HSC targeted surface engineered organic lipid nanoparticles.

Surface engineered lipid nanoparticles either actively or passively target trans-differentiated HSC through various cell surface receptors, such as Retinol-binding protein (RBP), Mannose-6- phosphate/insulin-like growth factor II (M6P/

Table 1: Methodology for the preparation of surface engineered lipid nanoparticulate DDS.

\begin{tabular}{|c|c|c|c|}
\hline Ligand & Lipid nano carrier & Methodology & Reference \\
\hline Vitamin A & Lipid nano particles & Direct mixing & {$[5]$} \\
\hline Vitamin A & Liposome & Direct mixing & {$[6,7]$} \\
\hline C*SRNLIDC* & Lipid nanoparticles & $\begin{array}{r}\text { Grafting of cyclic peptides on } \\
\text { phospholipids }\end{array}$ & {$[2,8]$} \\
\hline $\begin{array}{c}\text { CRGD* } \\
\text { peptide }\end{array}$ & $\begin{array}{c}\text { Sterically stable } \\
\text { Liposome }\end{array}$ & $\begin{array}{c}\text { Grafting of sulfhydryl group } \\
\text { at the cysteine residue to a } \\
\text { liposome }\end{array}$ & {$[9]$} \\
\hline M6P-HSA & $\begin{array}{c}\text { Neoglycoprotein-based } \\
\text { nanoparticles }\end{array}$ & Desolvation & {$[2]$} \\
\hline
\end{tabular}

IGF II), Platelet-derived growth factor receptor (PDGF- $\beta$ ), Hyaluronic acid (HA), Chemokines receptor type 4 (CXCR4) and galactosyl receptor conjugated with several ligands like cRGD* peptide, C*GRGDSPC* peptide, M6P, cyclic C*SRNLIDC* peptide, RBP via direct coating or grafting (Table 1$)[2,4]$.

Biocompatible and bio-degradable surface engineered lipid nano carrier should have sufficient internalization capacity by HSC, entrapment efficiency, penetrating power to interact with HSC for the treatment of hepatic fibrosis. However, the delivery of drug and gene through lipid-based nano carrier is limited by intrinsic and biological barriers [2,4]. Table 2 summarizes ligand-based lipid nanoparticulate approaches for targeting HSC.

\section{Conclusion and Future prospects}

Surface engineered lipid nanoparticles with various targeting ligands on the surface of HSCs become potent candidates for the treatment of hepatic fibrosis. Their higher biocompatibility, biodegradability and lower immunogenicity, toxicity compared to inorganic nanoparticles offer great advantages. ONPATTRO, the first FDA approved HSC-targeting lipid nano-particle, showed remarkable pharmacological effects by crossing hepatic barrier.Although HSC targeting has been challenging, the low quantity of surface engineered lipid nano-particles demonstrated significant therapeutic efficacy in clinical trials.

Table 2: Different formulation strategies of surface engineered lipid nanoparticles.

\begin{tabular}{|c|c|c|c|c|c|}
\hline Formulation & Ligand & $\begin{array}{l}\text { Targeted } \\
\text { receptor }\end{array}$ & Delivered drug & Remarks & Reference \\
\hline Liposome & $\mathrm{C} * \mathrm{SRNLIDC} *$ & PDGF $-\beta$ & $\begin{array}{l}\text { siRNA } \\
\text { and } \\
\text { Heat shock protein } \\
\text { 47-siRNA }\end{array}$ & $\begin{array}{l}\text { Remarkable gene silencing efficacy (37\%), anti-fibrotic effects } \\
\text { was observed. In-vivo and in-vitro study on mouse showed } \\
\text { significant extent of internalization by HSCs and } 2.37 \text { fold } \\
\text { higher liver uptake respectively compare to non-targeted } \\
\text { liposomes }\end{array}$ & {$[7,8]$} \\
\hline $\begin{array}{c}\text { Sterically stable } \\
\text { Liposome }\end{array}$ & cRGD* peptide & $\begin{array}{l}\text { Type VI } \\
\text { Collagen }\end{array}$ & IFN- $a-1 b$ & $\begin{array}{l}\text { Significant (10-fold) increased intracellular delivery of the drug } \\
\text { to HSCs was observed in bile duct ligation induced hepatic } \\
\text { fibrosis in Wistar rats than non-targeted liposomes. }\end{array}$ & {$[9,10]$} \\
\hline $\begin{array}{l}\text { Fluorescein } \\
\text { isothiocyanate- } \\
\text { conjugated Liposome }\end{array}$ & cRGD* peptide & $\begin{array}{l}\text { Type VI } \\
\text { Collagen }\end{array}$ & Oxymatrine & $\begin{array}{l}\text { There was notable down regulation of fibrosis-associated } \\
\text { biomarkers along with increased delivery of drug to HSCs in } \\
\text { CCI4-induced fibrosis in rats. In-vitro study revealed inhibited } \\
\text { cell viability and induced apoptosis of HSCs. }\end{array}$ & {$[4,11,12]$} \\
\hline Liposome & Vitamin A & RBP & $\begin{array}{l}\text { a. siRNA } \\
\text { b. Rho-kinase } \\
\text { inhibitor Y-27632 }\end{array}$ & $\begin{array}{l}\text { a. The expression of procollagen } 1 \text { was reduced in mice with } \\
\text { hepatic fibrosis by prolonging survival. } \\
\text { b. Conjugated liposome revealed } 100 \text { fold more effectiveness to } \\
\text { inhibit HSC activation than un-conjugated liposome. }\end{array}$ & {$[6,13,14]$} \\
\hline Liposome & M6P-HSA & M6P & $\begin{array}{l}\text { Sendai virus } \\
\text { containing plasmid } \\
\text { DNA }\end{array}$ & Efficient selective targeting of HSCs in mice was observed. & [15] \\
\hline Niosomal nano-vesicles & $\begin{array}{l}\text { Vitamin A and anti-platelet- } \\
\text { derived growth factor } \\
\text { receptor antibody }\end{array}$ & $\begin{array}{l}\text { RBP and } \\
\text { PDGF- } \beta\end{array}$ & $\begin{array}{l}\text { Silibinin, } \\
\text { iFluor }{ }^{\circledR} 790 \text { acid }\end{array}$ & $\begin{array}{c}\text { Antibody-conjugated nano-vesicles showed increased Silibinin } \\
\text { uptake ( } 4 \text { fold) in liver of mice at } 2 \mathrm{~h} \text { after dosing compare to } \\
\text { unconjugated niosomes. }\end{array}$ & {$[16,17]$} \\
\hline \multicolumn{4}{|l|}{ References } & \multicolumn{2}{|c|}{$\begin{array}{l}\text { 3. Mohanta BC, Dinda SC, Pali NN, Deb J (2019) Solid lipid based nano-particulate } \\
\text { formulations in drug targeting. In Tyagi, RK., Garg, N., Shukla, R., \& Bisen, PS. } \\
\text { (Eds), role of novel drug delivery vehicles in nanobiomedicine. IntechOpen } 30 \text {. } \\
\text { Link: https://bit.ly/2M8CHWM }\end{array}$} \\
\hline \multicolumn{4}{|c|}{$\begin{array}{l}\text { 2. Hu Q, Lee JY, Luo Y (2019) Nanoparticles targeting hepatic stellate cells } \\
\text { for the treatment of liver fibrosis. Engineered Science 6: 12-21. Link: } \\
\text { https://bit.ly/3cgF9Fk }\end{array}$} & \multicolumn{2}{|c|}{$\begin{array}{l}\text { 4. Böttger R, Pauli G, Chao PH, Fayez NA, Hohenwarter L, et al. (2020) Lipid- } \\
\text { based nanoparticles technologies for liver targeting. Adv Drug Deliv Rev 154: } \\
\text { 79-101. Link: https://bit.ly/2YsaWLj }\end{array}$} \\
\hline
\end{tabular}

Citation: Mukherjee S, Dutta A, Ash D (2021) Lipid nanoparticulate drug delivery system for the treatment of hepatic fibrosis. Arch Hepat Res 7(1): 001-003. 
5. Toriyabe N, Sakurai Y, Kato A, Yamamoto S, Tange K, et al. (2017) The delivery of small interfering RNA to hepatic stellate cells using a lipid nanoparticle composed of a vitamin A-scaffold lipid-like material. Journal of Pharmaceutical Sciences 106: 2046-2052. Link: https://bit.ly/3a8VwkS

6. Sato Y, Murase K, Kato J, Kobune M, Sato T, et al. (2008) Resolution of liver cirrhosis using vitamin A-coupled liposomes to deliver siRNA against a collagen-specific chaperone. Nat Biotechnol 26: 431-442. Link: https://bit.ly/36iG6cE

7. Jia Z, Gong Y, Pi Y, Liu X, Gao L, et al. (2018) pPB peptide-mediated siRNA loaded stable nucleic acid lipid nanoparticles on targeting therapy of hepatic fibrosis. Mol Pharm 15: 53-62. Link: https://bit.ly/3qXYBem

8. Zhang J, Shen H, Xu J, Liu L, Tan J, et al. (2020) Liver-targeted siRNA lipid nanoparticles treat hepatic cirrhosis by dual anti-fibrotic and anti-inflammatory activities. ACS Nano14: 6305-6322. Link: https://bit.ly/3prf3U2

9. Du SL, Pan H, Lu WY, Wang J, Wu J, et al. (2007) Cyclic Arg-Gly-Asp peptidelabeled liposomes for targeting drug therapy of hepatic fibrosis in rats. $J$ Pharmacol Exp Ther 322: 560-568. Link: https://bit.ly/39n60CE

10. Xuan J, Chen Y, Zhu L, Guo Y, Deng L, et al. (2017) Ultrasound molecular imaging with CRGD-PLGA-PFOB nanoparticles for liver fibrosis staging in a rat model. Oncotarget 8: 108676-108691. Link: https://bit.ly/3t3nhUw

11. Chai NL, Fu Q, Shi H, Cai CH, Wan J, et al. (2012) Oxymatrine liposome attenuates hepatic fibrosis via targeting hepatic stellate cells. World $\mathrm{J}$ Gastroenterol 18: 4199-4206. Link: https://bit.ly/2M1uBiX
12. Chan YT, Wang N, Tan HY, Li S, Feng Y (2020) Targeting hepatic stellate cells for the treatment of liver fibrosis by natural products: is it the dawning of a new era?. Front. Pharmacol 11: 16. Link: https://bit.ly/3otW0ae

13. Kuroda S, Tashiro H, Kimura Y, Hirata K, Tsutada M, et al. (2015) Rho-kinase inhibitor targeting the liver prevents ischemia/reperfusion injury in the steatotic liver without major systemic adversity in rats. Liver Transpl 21: 123131. Link: https://bit.ly/3ojlxmw

14. Klein S, Van Beuge MM, Granzow M, Beljaars L, Schierwagen R, et al. (2012) HSC-specific inhibition of Rho-kinase reduces portal pressure in cirrhotic rats without major systemic effects. J Hepatol 57: 1220-1227. Link: https://bit.ly/3iUvvJT

15. Adrian JE, Kamps JA, Poelstra K, Scherphof GL, Meijer DK, et al. (2007) Delivery of viral vectors to hepatic stellate cells in fibrotic livers using HVJ envelopes fused with targeted liposomes. J Drug Target 15: 75-82. Link: https://bit.ly/3oubACB

16. Hsu CY, Chen CH, Aljuffali IA, Dai YS, Fang JY (2017) Nano vesicle delivery to the liver via retinol binding protein and platelet-derived growth factor receptors: how targeting ligands affect bio-distribution. Nanomedicine 12 317-333. Link: https://bit.ly/2NzVf2A

17. Yang KY, Hwang du H, Yousaf AM, Kim DW, Shin YJ, et al. (2013) Silymarin-loaded solid nanoparticles provide excellent hepatic protection: physicochemical characterization and in vivo evaluation. Int J Nanomedicine 8: 3333-3343. Link: https://bit.ly/3ablump
Discover a bigger Impact and Visibility of your article publication with

Peertechz Publications
Highlights

* Signatory publisher of ORCID

* Signatory Publisher of DORA (San Francisco Declaration on Research Assessment)

- Articles archived in worlds' renowned service providers such as Portico, CNKI, AGRIS, TDNet, Base (Bielefeld University Library), CrossRef, Scilit, J-Gate etc.

* Journals indexed in ICMJE, SHERPA/ROMEO, Google Scholar etc.

- OAI-PMH (Open Archives Initiative Protocol for Metadata Harvesting)

* Dedicated Editorial Board for every journal

- Accurate and rapid peer-review process

* Increased citations of published articles through promotions

- Reduced timeline for article publication

Submit your articles and experience a new surge in publication services

(https://www.peertechz.com/submission).

Peertechz journals wishes everlasting success in your every endeavours.

Copyright: @ 2021 Mukherjee S, et al. This is an open-access article distributed under the terms of the Creative Commons Attribution License, which permits unrestricted use, distribution, and reproduction in any medium, provided the original author and source are credited.

Citation: Mukherjee S, Dutta A, Ash D (2021) Lipid nanoparticulate drug delivery system for the treatment of hepatic fibrosis. Arch Hepat Res 7(1): 001-003. 